Article

\title{
Diagenesis Evolution and Pore Types in Tight Sandstone of Shanxi Formation Reservoir in Hangjinqi Area, Ordos Basin, Northern China
}

\author{
Yue Zhang ${ }^{1}$, Jingchun Tian ${ }^{1,2, *}$, Xiang Zhang ${ }^{1,2, *}$, Jian Li ${ }^{3}$, Qingshao Liang ${ }^{1,2}$ and Xiaoyu Zheng ${ }^{1}$ \\ 1 Institute of Sedimentary Geology, Chengdu University of Technology, Chengdu 610059, China; \\ zhangyue@cdut.edu.cn (Y.Z.); liangqs@cdut.edu.cn (Q.L.); zhengxy1106@163.com (X.Z.) \\ 2 State Key Laboratory of Oil and Gas Reservoir Geology and Exploitation, Chengdu University of Technology, \\ Chengdu 610059, China \\ 3 College of Earth Science, Chengdu University of Technology, Chengdu 610059, China; lijian_cq1994@163.com \\ * Correspondence: tjc@cdut.edu.cn (J.T.); zhangxiang06@cdut.cn (X.Z.); Tel.: +86-1517-5385-192 (X.Z.)
}

check for

updates

Citation: Zhang, Y.; Tian, J.; Zhang,

X.; Li, J.; Liang, Q.; Zheng, X.

Diagenesis Evolution and Pore Types

in Tight Sandstone of Shanxi

Formation Reservoir in Hangjinqi

Area, Ordos Basin, Northern China.

Energies 2022, 15, 470. https://

doi.org/10.3390/en15020470

Academic Editor:

Mohamed Mahmoud

Received: 8 November 2021

Accepted: 5 January 2022

Published: 10 January 2022

Publisher's Note: MDPI stays neutral with regard to jurisdictional claims in published maps and institutional affiliations.

Copyright: () 2022 by the authors. Licensee MDPI, Basel, Switzerland. This article is an open access article distributed under the terms and conditions of the Creative Commons Attribution (CC BY) license (https:/ / creativecommons.org/licenses/by/ $4.0 /)$.

\begin{abstract}
Diagenesis and pore evolution of tight sandstone reservoir is one of the most important issues surrounding clastic reservoirs. The tight sandstone of the Shanxi Formation is an important oil and gas producing layer of the Upper Paleozoic in Ordos Basin, and its densification process has an important impact on reservoir quality. This study determined the physical properties and diagenetic evolution of Shanxi Formation sandstones and quantitatively calculated the pore loss in the diagenetic process. Microscopic identification, cathodoluminescence, and a scanning electron microscope were used identify diagenesis, and the diagenesis evolution process was clarified along with inclusion analysis. In addition, reservoir quality was determined based on the identification of pore types and physical porosity. Results show that rock types are mainly sublitharenite and litharenite. The reservoir has numerous secondary pores after experiencing compaction, cementation, and dissolution. We obtained insight into the relationship between homogenous temperature and two hydrocarbon charges. The results indicated that there were two hydrocarbon charges in the Late Triassic-Early Jurassic $\left(70-90^{\circ} \mathrm{C}\right)$ and Middle Jurassic-Early Cretaceous $\left(110-130^{\circ} \mathrm{C}\right)$ before reservoir densification. The quantitative calculation of pore loss shows that the average apparent compaction, cementation, and dissolution rates are $67.36 \%, 22.24 \%$, and $80.76 \%$, respectively. Compaction directly affected the reservoir tightness, and intense dissolution was beneficial to improve the physical properties of the reservoir.
\end{abstract}

Keywords: tight sandstone reservoir; diagenesis; densification; pore evolution; diagenetic evolution

\section{Introduction}

Tight sandstone has become the major target of oil or gas exploration, and interest has developed worldwide [1-3]. The Ordos Basin is one of the most considerable gas producing basins in China, where several large oil and gas fields have been discovered in the central area [4-6]. There is no doubt that the exploration target of the Ordos Basin derives from the Lower Paleozoic to Upper Paleozoic [7-9], but the tight sandstones are mainly concentrated in the Permian $[9,10]$.

Reservoir quality is mainly affected by the sedimentary environment and diagenetic evolution [11-14]. Porosity and permeability are affected by grain size, sorting, depositional structure, depositional environment, subsequent types, and diagenesis process [15]. Compaction, cementation, and dissolution have an impact on physical properties [15-17]. With the increasing intensity of compaction, reservoir physical properties became decreased [17], and many unstable minerals dissolution produced secondary pores to improve the physical properties $[18,19]$. Therefore, many secondary pores were associatedwith complex diagenesis. 
The Shanxi Formation is the target for coalbed methane in the northern Ordos Basin. Researchers use fractal theory and X-ray computed tomography to study pore connectivity [20]. Sequence stratigraphy [21], sedimentary systems [22-24], provenance [25,26], the controlling factors of reservoir, [27-32], and diagenesis evolution [33,34] have gradually been noted. These studies indicate that the sandstone reservoir of the Shanxi Formation is tight. Therefore, this paper combines physical properties and diagenesis in the Shanxi Formation reservoir to quantitatively calculate pore loss from diagenesis and determine the time of different diagenetic. The implications of the presented results may have a significant impact on the exploration and development of tight oil reservoirs in other tight reservoir regions worldwide.

\section{Geological Setting}

The Ordos Basin is located in northern China, and the area is approximately $25 \times$ $10^{4} \mathrm{~km}^{2}$. It is a polycyclic craton basin and contains many large-scale gas fields [35-37]. The Ordos Basin consists of six structural units (Figure 1a): Yimeng Uplift in the north, Weibei Uplift in the south, from the west to east is the western Thrust Belt, Tianhuan Depression, Yishan Slope, and Jinxi Fault-Fold Belt [26,38]. The Hangjinqi area is located in the north of the Ordos Basin; it mainly developed in an east-west direction fault, which is called the Porjianghaizi Fault [39]. There are three secondary structural units (Figure 1c), including Gongkahan Uplift, Hangjinqi Fault Terrace, and Yishan Slope [10,39]. The total area is approximately $9800 \mathrm{~km}^{2}$.

The Taiyuan, Shanxi, Shihezi, and Shiqianfeng Formations were deposited successively in the Permian [10]. The sedimentary facies in the northern Ordos Basin had undergone a period of transformation from marine facies to continental facies in the Paleozoic [21,22,40]. The provenance of the Shanxi Formation in the Hangjinqi area was mainly from the Yinshan paleocontinent $[24,26]$. It developed a delta plain, including a distributary channel, pest swamp, depression sedimentary, and floodplain microfacies (Figure 1b) [24]. These all show the distribution of facies zones from north to south [41,42]. The sedimentary thickness of the Shanxi Formation is $23.6-90.0 \mathrm{~m}$, with an average thickness of $52.2 \mathrm{~m}$. It can be subdivided into two Members, namely Shan 1 and Shan 2 Members from the bottom to the top [9,43]. Sandstones of Shan 1 Member are coarse and fine sandstone, which is characterized by peat interbedding. The sandstones in Shan 2 Member are primarily composed of medium to fine-grained sandstone, gravelly coarse sandstone, and gray mudstone at the top. 


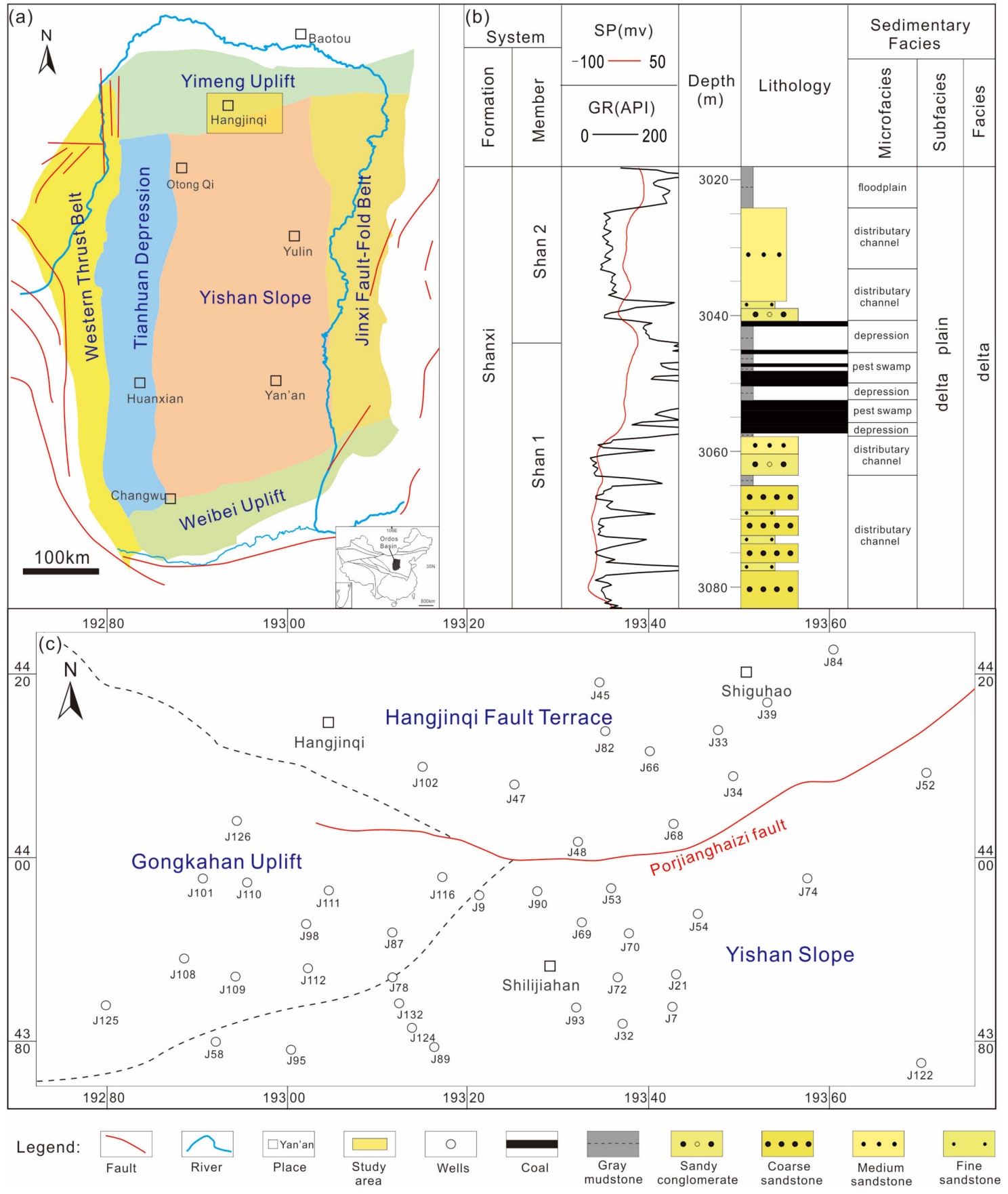

Figure 1. (a) Structural units and geographical location of the study area; (b) Stratigraphic system and sedimentary facies map of Shanxi Formation; (c) Tectonic units and wells location. Geographic location and stratigraphic sedimentary facies of the Shanxi Formation in the Hangjinqi Area [39].

\section{Methods}

All plunger samples were obtained by drilling cores. In this study, 120 thin sections and casting thin sections were identified. In total, 80 samples were analyzed by scanning electron microscope (SEM), 24 samples by cathodoluminescence (CL), and 29 samples by inclusion homogenization. The porosity and permeability of 238 data points were obtained by conventional physical tests. The wells' location is shown in Figure 1c. All experiments were conducted in the State Key Laboratory of Oil and Gas Reservoir Geology and Exploitation, Chengdu University of Technology. 
Petrologically, characteristics were observed using conventional thin sections, including detrital components, interstitial, and diagenetic phenomena. Cast thin sections were filled with blue epoxy, which was used to identify the pore types and thin-section porosity. The thin sections and cast thin sections photomicrographs were obtained by optical microscope (Nikon LV100POL).

Microscopic measurements were carried out by an image analysis system; each sample was selected at 300 measurements points. In order to achieve the purpose of measuring the overall shape grains, the cursor was moved along a straight line to measure the grain diameter.

CL is mainly based on the MK5 system, using CL8200 to analyze the polished sheet under $18 \mathrm{KV}$ and $280 \mu \mathrm{A}$. The morphology of clay mineral was analyzed by SEM with a Hitachi S-3000N (maximum resolution $3.5 \mathrm{~nm}$ ). The working voltage was $25 \mathrm{KV}$, and amplification was $35 \times$ to $3000 \times$.

The inclusions were observed under a microscope to determine the type of inclusion and gas charging period, which will be helpful to the division of diagenetic stages. The thin sheets were placed on a specific cold and hot platform, which has a certain gas-liquid ratio (linkam THMSG600 cooling and heating table). We observed the reversible phase change from a gas-liquid two-phase to a single liquid phase. As the temperature increased, the proportion of gas-liquid phase changed. With the increase of temperature again, the gasliquid two phase inclusions changed into a single liquid phase. At present, the temperature is called homogenization temperature.

The obtained results are based on thin-section identification and grain analysis to calculate the strength of related diagenesis. Sorting efficient $\left(S_{0}\right)$ is generally used to calculate the original porosity. The relationship between the original porosity and the estabilished sorting coefficient is as follows [44]:

$$
\Phi_{0}=20.91+\frac{22.90}{S_{0}}
$$

$S_{0}=P_{25} / P_{75}$ (where $\Phi_{0}$ is the original porosity, $P_{25}$ and $P_{75}$ are the grains diameters $(\mathrm{mm})$ at $25 \%$ and $75 \%$ of the cumulative curve.)

The apparent compaction rate, apparent cementation rate, and apparent dissolution rate [45] were used to quantitatively evaluate the strength of various diagenesis and the influence on pore evolution.

The apparent compaction rate $\Phi_{1}$,

$$
\Phi_{1}=\left[\frac{V_{O}-V_{P}}{V_{O}} \times 100 \%\right]
$$

$V_{O}$ is the original pore volume and $V_{P}$ is the percentage of the intergranular volume in the total volume of rock after compaction.

The apparent cementation rate $\Phi_{2}$,

$$
\Phi_{2}=\frac{V_{C}}{V_{O}} \times 100 \%
$$

$V_{C}$ is the percentage of residual cement in the total volume of the rock.

The apparent dissolution rate $\Phi_{3}$,

$$
\Phi_{3}=\frac{\text { Dissolved face rate }}{\text { Total face rate }} \times 100 \%
$$

These methods are used for determining the reservoir lithology and physical property characteristics of pores, the diagenetic evolution stage, and quantitative analysis of the porosity evolution in the Shanxi Formation of the Hangjinqi area. 


\section{Results}

\subsection{Petrological Characteristic}

Through the observation of 120 thin sections, the rock types of the Shanxi Formation in the study area are mainly sublitharenite and litharenite (Figures 2 and $3 a, b)$. The grain size is $0.3-0.8 \mathrm{~mm}$, with medium to poor sorting, average roundness, and low structure maturity. The grains are mainly in line contact, and some of them are in concave-convex contact. Quartz content ranges from 50\% to 95\%, with an average of $72.15 \%$. There is a small amount of chalcedony (Figure 3c), and part of the quartz is polycrystalline quartz (Figure 3d). Feldspar content was generally less than $4.0 \%$, with an average of $2.0 \%$. The rock fragments content is $8.0-50 \%$, with an average of $28.91 \%$. The rock fragments under the microscope are mainly metaquatrzite and mudstone debris (Figure $3 \mathrm{e}, \mathrm{f}$ ). The types of cement are mainly carbonate, siliceous, and kaolinite. The matrix was mainly iron (mud) debris (Table 1 ). The error range is $\pm 3 \%$.

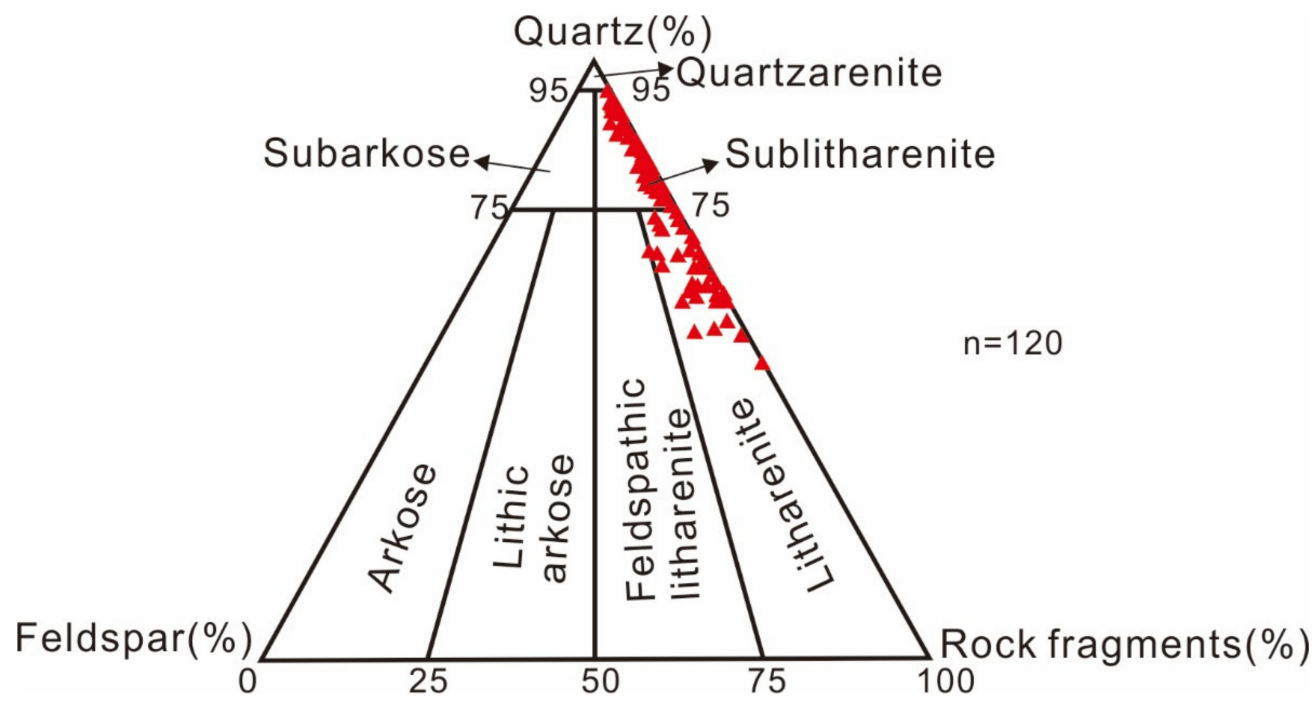

Figure 2. Classification of the Shanxi Formation sandstone using Folk's [46] classification.
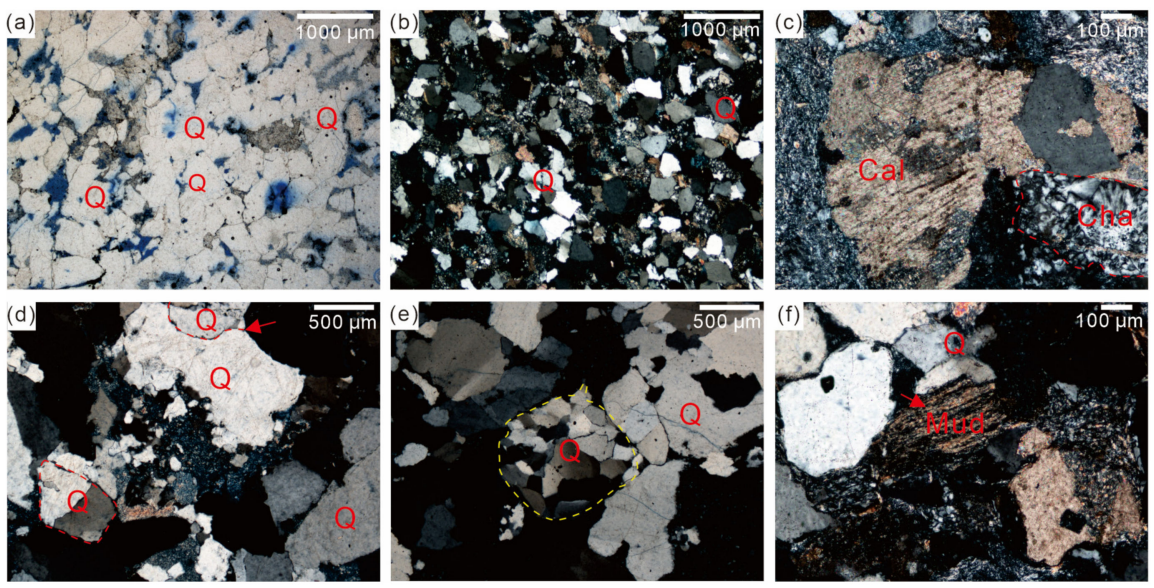

Figure 3. (a) Photomicrograph of sublitharenite from well J115 at $3225.68 \mathrm{~m}$ in Shan 1 Member; (b) Photomicrograph of litharenite from well J87 at $3065.02 \mathrm{~m}$ in Shan 2 Member; (c) Photomicrograph of chalcedony and calcite cementation from well J72 at $3071.28 \mathrm{~m}$ in Shan 1 Member; (d) Photomicrograph of polycrystalline quartz and line contact between quartz from well J30 at $3095.16 \mathrm{~m}$ in Shan 2 Member; (e) Photomicrograph of quartz debris from well J124 at $3141.94 \mathrm{~m}$ in Shan 1 Member; (f) Photomicrograph of mudstone debris from well J72 at $2987.36 \mathrm{~m}$ in Shan 2 Member. Petrologic characteristics of Shanxi Formation reservoir. 
Table 1. Petrological composition of the Shanxi Formation reservoir in the Hangjinqi area.

\begin{tabular}{ccccc}
\hline & & Min (\%) & Max (\%) & Average Content (\%) \\
\hline \multirow{4}{*}{ Clastic } & Quartz & 48 & 95 & 72.15 \\
component & Feldspar & 0 & 4 & 1.26 \\
& Rock fragments & 1 & 50 & 17.20 \\
& Quartzite & 3 & 24 & 9.6 \\
& Phyllite and schist & 0 & 6 & 3.72 \\
& Siltstone & 0 & 5 & 4.5 \\
Cement & Mudstone & 0 & 16 & 5.21 \\
& Calcite & 0 & 10 & 9.14 \\
\hline \multirow{2}{*}{ Matrix } & Kaolinite & 0 & 30 & 2.0 \\
\hline
\end{tabular}

\subsection{Diagenesis}

\subsubsection{Compaction}

There are three main forms of compaction in the Shanxi Formation: the fracture of rigid grains (quartz), the bending deformation of mudstone or mica, and the rearrangement of skeleton grains. Intense compaction forced the grains close to each other (Figure 4a). The connect code of clastic grains was adjusted from point-like connect to linear (Figure $4 \mathrm{~b}$ ) or concave-convex contacts. These all lead primary intergranular pores were greatly reduced after compaction.
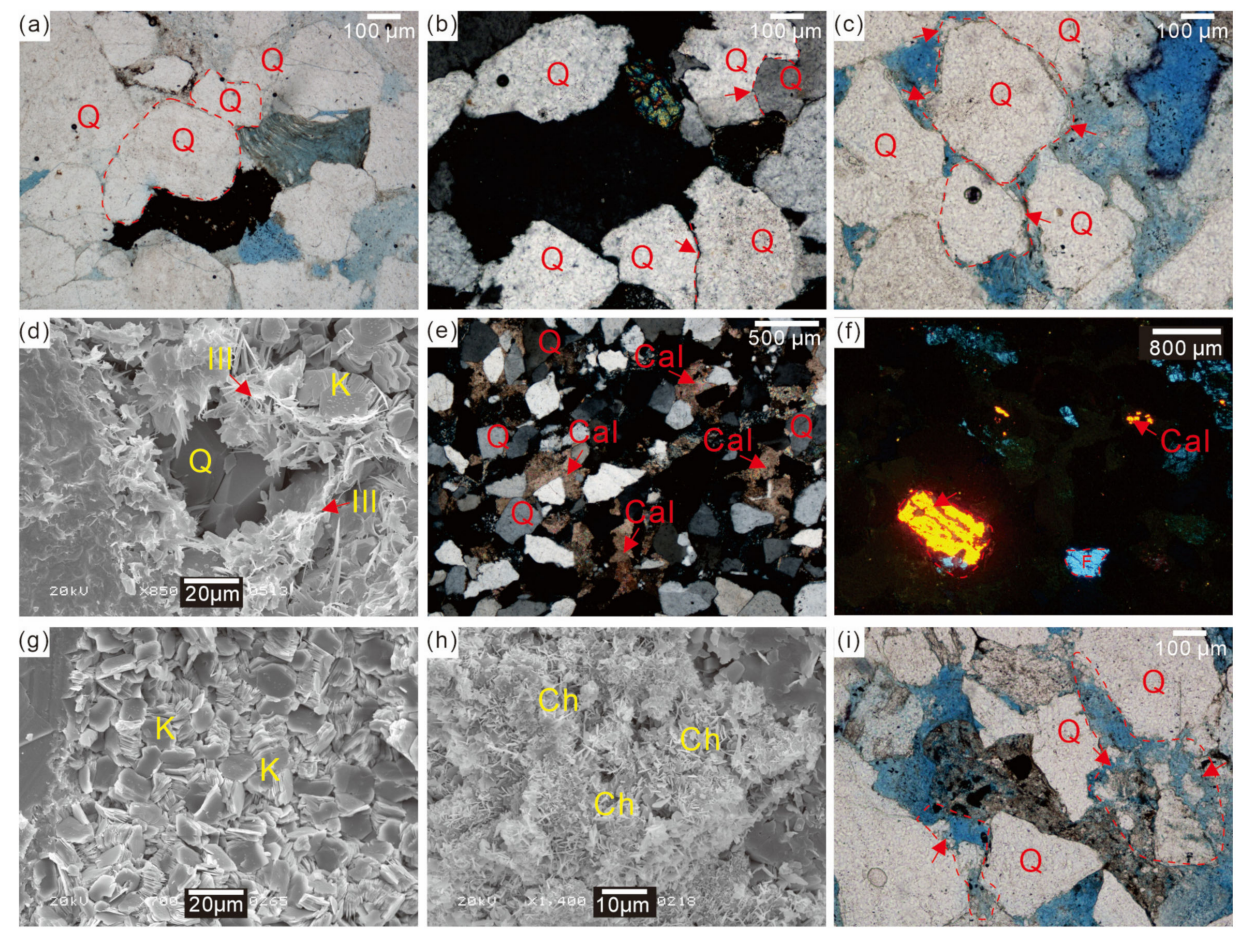

Figure 4. (a) The grains are in linear contact from well J72 at $3000.97 \mathrm{~m}$ in Shan 1 Member; (b) Photomicrograph of linear contact between grains from well J72 at $3000.97 \mathrm{~m}$ in Shan 1 Member; (c) Photomicrograph of the secondary edge of quartz is dissolved from well J78 at $3092.77 \mathrm{~m}$ in Shan 2 Member; (d) SEM images of fibrous illite, kaolinite and authigenic quartz fills intergranular pores from well J124 at $3141.94 \mathrm{~m}$ in Shan 1 Member; (e) Photomicrograph of the calcite cementation from well J122 at $2812.88 \mathrm{~m}$ in Shan 1 Member; (f) CL images of feldspar was dissolved and eroded into calcite from well J78 at $3092.77 \mathrm{~m}$ in Shan 2 Member; (g) SEM images of flaky kaolinite from well J78 at $3092.77 \mathrm{~m}$ in Shan 2 Member; (h) SEM images of foliaceous chlorite from well J69 at $2987.42 \mathrm{~m}$ in Shan 2 Member; (i) Photomicrograph of dissolution cuts through the grains from well J78 at $3092.77 \mathrm{~m}$ in Shan 2 Member. Microcosmic characteristics of Shanxi Formation in the study area. 


\subsubsection{Cementation}

Siliceous, carbonate, and clay minerals are the common types of cement in the Shanxi Formation tight sandstone of the Hangjinqi area. Microscopic observation and scanning electron microscopy have revealed two stages of siliceous cementation. The early quartz cementation was quartz overgrowths (Figure 4c). The late quartz cementation was dominated by authigenic quartz, distributed among the intergranular and mostly surrounded by clay minerals (Figure $4 \mathrm{~d}$ ).

The carbonate cementation was mainly calcite cementation in the Shanxi Formation (Figure 4e). Calcite often cemented quartz, which was found by microscopic and CL characteristics. CL can distinguish whether there is calcite in rocks; most iron-containing calcite is dark-red, while ferrocalcite is orange-red (Figure 4f).

Authigenic clay mineral consists of kaolinite, illite, and some chlorite. Kaolinite exists in the form of pages and sheets (Figure $4 \mathrm{~g}$ ); illite is mainly fibrous. Chlorite is partly attached to the surface of clastic grains to form a chlorite ring edge (Figure $4 \mathrm{~h}$ ).

\subsubsection{Metasomatism}

The sedimentary facies from the Taiyuan Formation to the Shanxi Formation are marine to continental; the environment reducing the oxidation environment alternated at the same time, so the coal seam appeared in the Shanxi Formation [47]. Most feldspar had eroded into calcite after dissolution (Figure 4f), which was accompanied with large amounts of intergranular pores. The dissolution of acidic media created intergranular pores that improved the reservoir quality.

\subsubsection{Dissolution}

In the Shanxi Formation, feldspar, debris, and some authigenic minerals were dissolved (Figure 4i). Modic pores were formed after feldspar or debris dissolved. Some intergranular pores were surrounded by authigenic minerals such as quartz overgrowths and kaolinite. This show that the authigenic minerals were formed by pressure dissolution.

\subsection{Reservoir Properties}

\subsubsection{Pore Types}

The Shanxi Formation reservoir, besides primary pores, also have many secondary pores, such as intergranular dissolved pores, intragranular dissolved pores, and so on $[29,48,49]$. The average content of intergranular dissolved pores in Shan 1 Member is $3.3 \%$ and in Shan 2 Member is $1.7 \%$, with the average content being $2.6 \%$. The average intragranular dissolved pores in Shan 1 and Shan 2 Members are 2.1\% and 2.2\%. The average content is $2.2 \%$.

The primary pores of the Shanxi Formation are mainly intergranular pores (Figure 5a). Most of the pores were filled by authigenic quartz and kaolinite. Chlorite can be seen at the edge of quartz, with good pores connectivity.

Secondary pores were formed by dissolution, which mainly appeared at the external or interior of clastic grains (Figure $5 b, c$ ). When the acid solution entered the reservoir, feldspar and rock debris dissolved to form intragranular pores [48-50]. The grains were completely dissolved to be moldic pores (Figure 5d). It mostly occurred in unstable rocks debris such as feldspar and some rock fragments.

Kaolinite filled some intergranular dissolved pores in the Shanxi Formation, and the intergranular pores of kaolinite can be seen under SEM (Figure 5e,f). 

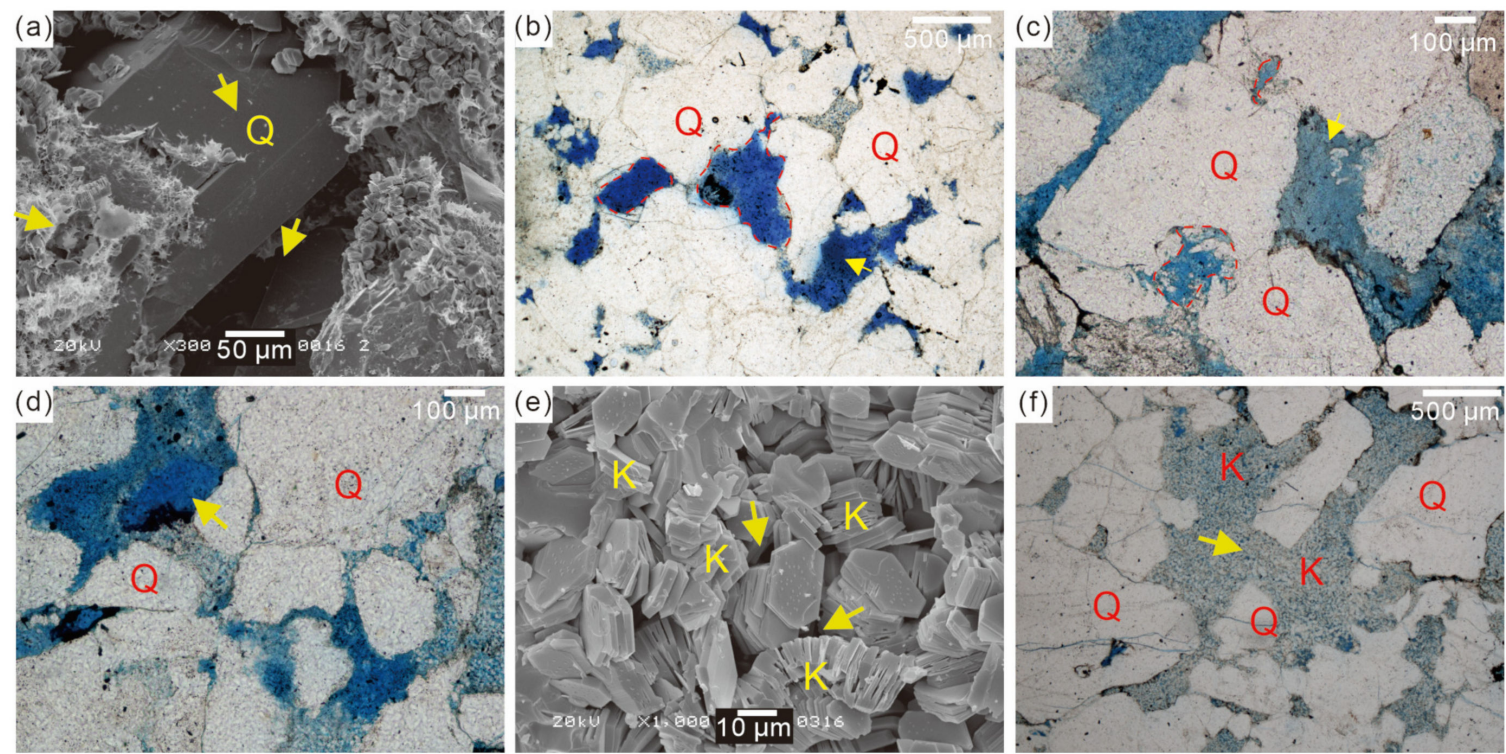

Figure 5. (a) SEM images of second quartz filled residual primary intergranular pores, kaolinite and illite are attached to the surface of the quartz grains from well J32 at $3003 \mathrm{~m}$ in Shan 1 Member; (b) Photomicrograph of moldic pores represented by red lines, intergranular pores represented by yellow lines, yellow arrow indicates intragranular solution pores form well J115 at $3225.68 \mathrm{~m}$ in Shan 1 Member; (c) Photomicrograph of intergranular pores from well J78 at $3092.77 \mathrm{~m}$ in Shan 2 Member; (d) Photomicrograph of moldic pores from well J72 at $3007.63 \mathrm{~m}$ in Shan 1 Member; (e) SEM images of kaolinite intercrystalline pores, kaolinite occurs as sheets and book from well J89 at $3163.19 \mathrm{~m}$ in Shan 1 Member; (f) Photomicrograph of kaolinite filled with some intergranular solution pores, kaolinite is worm-like from well J124 at $3141.94 \mathrm{~m}$ in Shan 1 Member. Pore types of Shanxi Formation in the study area.

\subsubsection{Porosity and Permeability}

According to the physical analysis, the porosity of the Shan 1 Member is $1.5-14 \%$, with an average porosity of $8.1 \%$, focused on the range of $5-9 \%$. The porosity of the Shan 2 Member is $0.4-15.45 \%$, and the average porosity is $4.4 \%$. The permeability of Shan 1

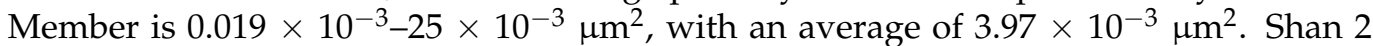

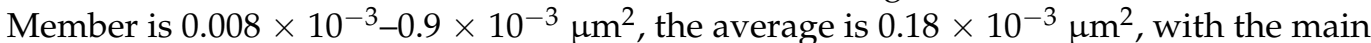
distribution less than $0.1 \times 10^{-3} \mu^{2}$. In summary, the porosity and permeability are positively correlation (Figure 6).

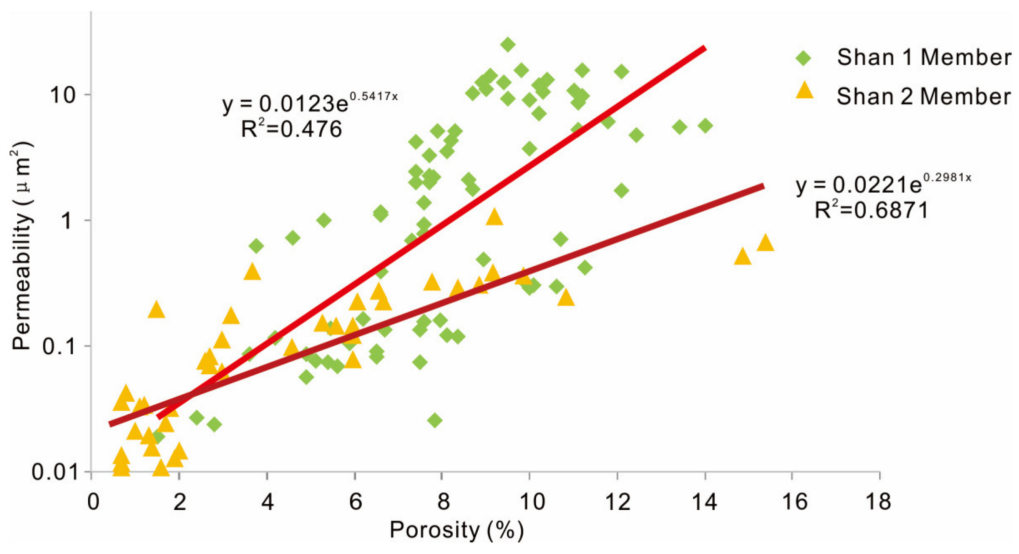

Figure 6. Correlation diagram of porosity and permeability distribution of sandstone reservoir in Shanxi Formation. 


\subsection{Fluid Inclusions}

Fluid inclusions are the original diagenetic fluids retained during the crystallization of minerals and reflect the geological history [50]. The Shanxi Formation inclusions in the Hangjinqi area are commonly observed in quartz which can be divided into inorganic saltwater inclusions, gaseous hydrocarbon inclusions, and so on [51,52]. By analyzing the temperature measurement data of 29 inclusions of the Shanxi Formation in the study area, it can be found that the fluid inclusions are mostly dispersed in the quartz cement. There are two peak values of inclusion homogenization temperature in the quartz cement (Figure 7). The inclusion homogenization is concentrated in the range of $70-90{ }^{\circ} \mathrm{C}$ and $110-130{ }^{\circ} \mathrm{C}$ (Table 2).

Table 2. The inclusion homogenization of the Shanxi Formation in the Hangjinqi area.

\begin{tabular}{|c|c|c|c|c|}
\hline Number & Well & Member & Depth (m) & Inclusion Homogenization $\left({ }^{\circ} \mathrm{C}\right)$ \\
\hline 1 & J132 & Shan1 & 3127.4 & 86.1 \\
\hline 2 & $\mathrm{~J} 132$ & Shan 1 & 3127.4 & 98.7 \\
\hline 3 & J89 & Shan 1 & 3157.5 & 99.5 \\
\hline 4 & J89 & Shan 1 & 3157.5 & 128.4 \\
\hline 5 & $\mathrm{~J} 72$ & Shan 1 & 3009.6 & 73.1 \\
\hline 6 & $\mathrm{~J} 72$ & Shan 1 & 3009.6 & 84.3 \\
\hline 7 & $\mathrm{~J} 72$ & Shan 1 & 3009.6 & 86.8 \\
\hline 8 & J72 & Shan 2 & 2989.3 & 102.1 \\
\hline 9 & J72 & Shan 2 & 2989.3 & 122.2 \\
\hline 10 & $\mathrm{~J} 72$ & Shan 2 & 2989.3 & 126.4 \\
\hline 11 & J78 & Shan 2 & 3095.7 & 70.2 \\
\hline 12 & J78 & Shan 2 & 3095.7 & 75.6 \\
\hline 13 & J87 & Shan 2 & 3065.0 & 82.9 \\
\hline 14 & J87 & Shan 2 & 3065.0 & 117.3 \\
\hline 15 & J87 & Shan 2 & 3065.0 & 145.7 \\
\hline 16 & J124 & Shan 1 & 3141.9 & 86.3 \\
\hline 17 & J124 & Shan 1 & 3141.9 & 82.8 \\
\hline 18 & J124 & Shan 1 & 3141.9 & 80.1 \\
\hline 19 & J111 & Shan 1 & 3071.3 & 134.6 \\
\hline 20 & J111 & Shan 1 & 3071.3 & 106.2 \\
\hline 21 & J111 & Shan 1 & 3071.3 & 112.5 \\
\hline 22 & J69 & Shan 2 & 2987.4 & 55.4 \\
\hline 23 & J69 & Shan 2 & 2987.4 & 61.6 \\
\hline 24 & J69 & Shan 2 & 2987.4 & 68.4 \\
\hline 25 & J69 & Shan 2 & 2987.4 & 53.7 \\
\hline 26 & $\mathrm{~J} 78$ & Shan 2 & 3092.8 & 111.3 \\
\hline 27 & $\mathrm{~J} 78$ & Shan 2 & 3092.8 & 120.7 \\
\hline 28 & J78 & Shan 2 & 3092.8 & 127.2 \\
\hline 29 & J78 & Shan 2 & 3092.8 & 148.2 \\
\hline
\end{tabular}



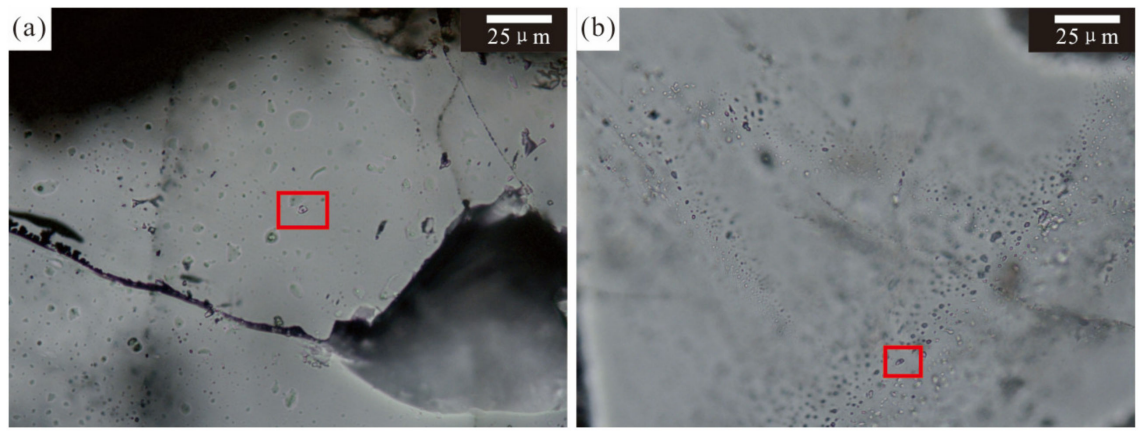

Figure 7. (a) Well J78, $3095.72 \mathrm{~m}, 82.9^{\circ} \mathrm{C}, 2.8 \mu \mathrm{m}$, Shan 2 Member; (b) Well J72, 2989.37 m, $126.4^{\circ} \mathrm{C}$, $5.5 \mu \mathrm{m}$, Shan 2 Member. Microscopic characteristics of inclusions of the Shanxi Formation in the study area.

\section{Discussion}

\subsection{Quantitative Calculation of Pore Loss}

The value of $\Phi_{1}, \Phi_{2}$, and $\Phi_{3}$ are used for quantitative analysis to determine the strength of diagenesis [45] and pore evolution history. According to the grain size structure of sandstone in the Shanxi Formation, the average value of $S_{0}$ is 1.7, the original porosity $\Phi_{0}$ is $32.59-36.38 \%$, and the average value is $34.61 \%$ (Table 3).

Table 3. Pore evolution of the Shanxi Formation in the Hangjinqi area.

\begin{tabular}{|c|c|c|c|c|c|c|c|c|c|c|}
\hline Number & Well & $\begin{array}{l}\text { Depth } \\
\text { (m) }\end{array}$ & $\mathbf{D}_{1}$ & $\mathrm{D}_{2}$ & $S_{0}$ & $\Phi_{0}(\%)$ & $\begin{array}{l}\text { Content of } \\
\text { Cement }(\%)\end{array}$ & $\Phi_{1}(\%)$ & $\Phi_{2}(\%)$ & $\Phi_{3}(\%)$ \\
\hline 1 & J9 & 3127 & 1.03 & 0.68 & 1.51 & 36.10 & 5.00 & 73.68 & 13.85 & 97.01 \\
\hline 2 & J122 & 2812 & 0.57 & 0.37 & 1.54 & 35.77 & 6.00 & 80.43 & 16.77 & 60.00 \\
\hline 3 & J115 & 3225 & 1.06 & 0.68 & 1.56 & 35.60 & 6.00 & 64.89 & 16.85 & 82.35 \\
\hline 4 & J111 & 3158 & 0.74 & 0.50 & 1.48 & 36.38 & 3.00 & 89.00 & 8.24 & 75.00 \\
\hline 5 & J124 & 3162 & 0.91 & 0.49 & 1.87 & 33.14 & 5.00 & 75.86 & 15.09 & 70.00 \\
\hline 6 & J87 & 3065 & 0.82 & 0.51 & 1.60 & 35.26 & 10.00 & 47.54 & 28.36 & 96.00 \\
\hline 7 & $\mathrm{~J} 72$ & 3000 & 1.70 & 0.88 & 1.93 & 32.76 & 8.00 & 69.48 & 24.42 & 92.86 \\
\hline 8 & $\mathrm{~J} 72$ & 3008 & 1.05 & 0.65 & 1.62 & 35.09 & 12.00 & 53.54 & 34.20 & 95.80 \\
\hline 9 & J78 & 3163 & 1.00 & 0.51 & 1.96 & 32.59 & 15.00 & 54.59 & 46.03 & 97.66 \\
\hline 10 & J108 & 3151 & 0.84 & 0.55 & 1.53 & 35.90 & 3.00 & 57.66 & 8.36 & 96.97 \\
\hline 11 & J93 & 3068 & 1.06 & 0.55 & 1.93 & 32.79 & 11.00 & 46.02 & 33.54 & 98.29 \\
\hline 12 & $\mathrm{~J} 21$ & 2917 & 0.74 & 0.45 & 1.64 & 34.84 & 8.00 & 91.68 & 22.96 & 55.55 \\
\hline 13 & $\mathrm{~J} 48$ & 2536 & 0.69 & 0.41 & 1.68 & 34.52 & 1.00 & 76.82 & 2.89 & 40.00 \\
\hline 14 & $\mathrm{~J} 7$ & 2973 & 0.88 & 0.52 & 1.69 & 34.44 & 5.00 & 78.22 & 14.52 & 54.55 \\
\hline 15 & J78 & 3093 & 0.90 & 0.53 & 1.70 & 34.40 & 5.00 & 75.29 & 14.54 & 88.89 \\
\hline 16 & $\mathrm{~J} 30$ & 3596 & 1.12 & 0.65 & 1.73 & 34.15 & 7.00 & 79.50 & 20.50 & 80.00 \\
\hline 17 & J70 & 2961 & 0.89 & 0.62 & 1.48 & 36.34 & 6.00 & 73.85 & 16.51 & 46.15 \\
\hline 18 & $\mathrm{~J} 78$ & 3093 & 0.85 & 0.49 & 1.72 & 34.25 & 9.00 & 62.62 & 26.28 & 89.74 \\
\hline 19 & J87 & 3075 & 0.83 & 0.49 & 1.69 & 34.43 & 8.00 & 55.86 & 23.23 & 88.23 \\
\hline 20 & $\mathrm{~J} 29$ & 3670 & 0.92 & 0.59 & 1.55 & 35.71 & 10.00 & 50.99 & 28.00 & 74.07 \\
\hline 21 & $\mathrm{~J} 72$ & 3011 & 1.08 & 0.61 & 1.77 & 33.88 & 13.00 & 53.66 & 38.37 & 86.61 \\
\hline 23 & J9 & 3076 & 1.32 & 0.72 & 1.82 & 33.53 & 12.00 & 71.97 & 35.80 & 81.08 \\
\hline
\end{tabular}

After compaction, the grains were in close contact, and porosity was reduced by $32.75 \%$. The average value of $\Phi_{1}$ was $67.36 \%$. Cementation mainly affected reservoir porosity through chlorite rings and carbonate cementation. The chlorite rings were at the edge of quartz grains. Carbonate cementation hindered the reservoir development. The average value of $\Phi_{2}$ was $22.24 \%$. In the shallow burial stage, under the influence of acidic medium water, feldspar was dissolved and resulted in secondary pores $[53,54]$. The average value of $\Phi_{3}$ was $80.76 \%$ in the Shanxi Formation reservoir. However, with the continuous strengthening of compaction, many primary pores were destroyed. The residual primary intergranular pores of sandstone were filled by cementation, which decreased the reservoir physical property. Dissolution is the major controlling factor for the formation of high-quality reservoirs in tight sandstone. 
By analyzing the calculation results, the sandstones of the Shanxi Formation has experienced moderate compaction, weak cementation, and strong dissolution. Therefore, a great number of secondary pores were developed in the Shanxi Formation.

\subsection{The Time of Different Diagenetic Stage}

Based on paleogeotemperature and vitrinite reflectance $\left(R_{0}\right)$ to the divided diagenetic stage, the diagenetic sequence of Shanxi Formation sandstone in Hangjinqi area is summarized. The Shanxi Formation has experienced eodiagenesis and mesodiagenesis. This study reconstructed the evolution process of diagenesis.

\subsubsection{Eodiagenesis}

A burial depth less than $2200 \mathrm{~m}$, temperature lower than $85^{\circ} \mathrm{C}$, and $\mathrm{R}_{\mathrm{o}}<0.5 \%$ is recognized as eodiagenesis. In stage $\mathrm{A}$ of eodiagenesis, the plastic and rigid components were deformed and fractured. During this time, lots of original pores reduced or disappeared. Quartz overgrowth blocked the primary pores, and a small amount of chlorite ring edges around the quartz surface. These phenomena indicated quartz overgrowth was formed earlier than chlorite. Chlorite has a certain protective effect on primary pores [55-57]. With microscopic observation, the iron-ferrocalcite often cemented quartz. Affected by the intense compaction and early cementation, porosity substantially declined.

During the Late Triassic to Early Jurassic, the reservoir of the Shanxi Formation was placed into stage B of eodiagenesis. The burial depth was 1500-2200 m, and the paleotemperature ranged from $70{ }^{\circ} \mathrm{C}$ to $90{ }^{\circ} \mathrm{C}$ (Figure 8). The Shanxi Formation is a coal measure stratum, $\mathrm{H}^{+}$is produced under oxidation conditions [58], promoting the occurrence of dissolution [52,56,59]. By observing the homogenization temperature of inclusions in quartz cement, a large number of inclusions were formed in this period and oil and gas began to appear (Figure 9). Organic acids were released in hydrocarbon generation, which promoted dissolution and produced plentiful secondary pores in the Shanxi Formation.

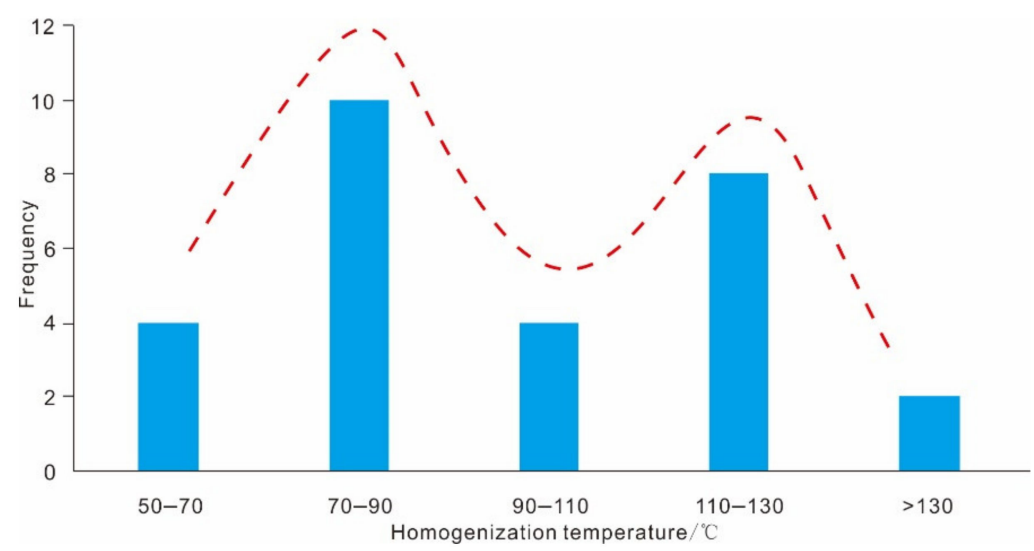

Figure 8. Histogram of inclusions homogenization temperature distribution of the Shanxi Formation $(n=29)$. 


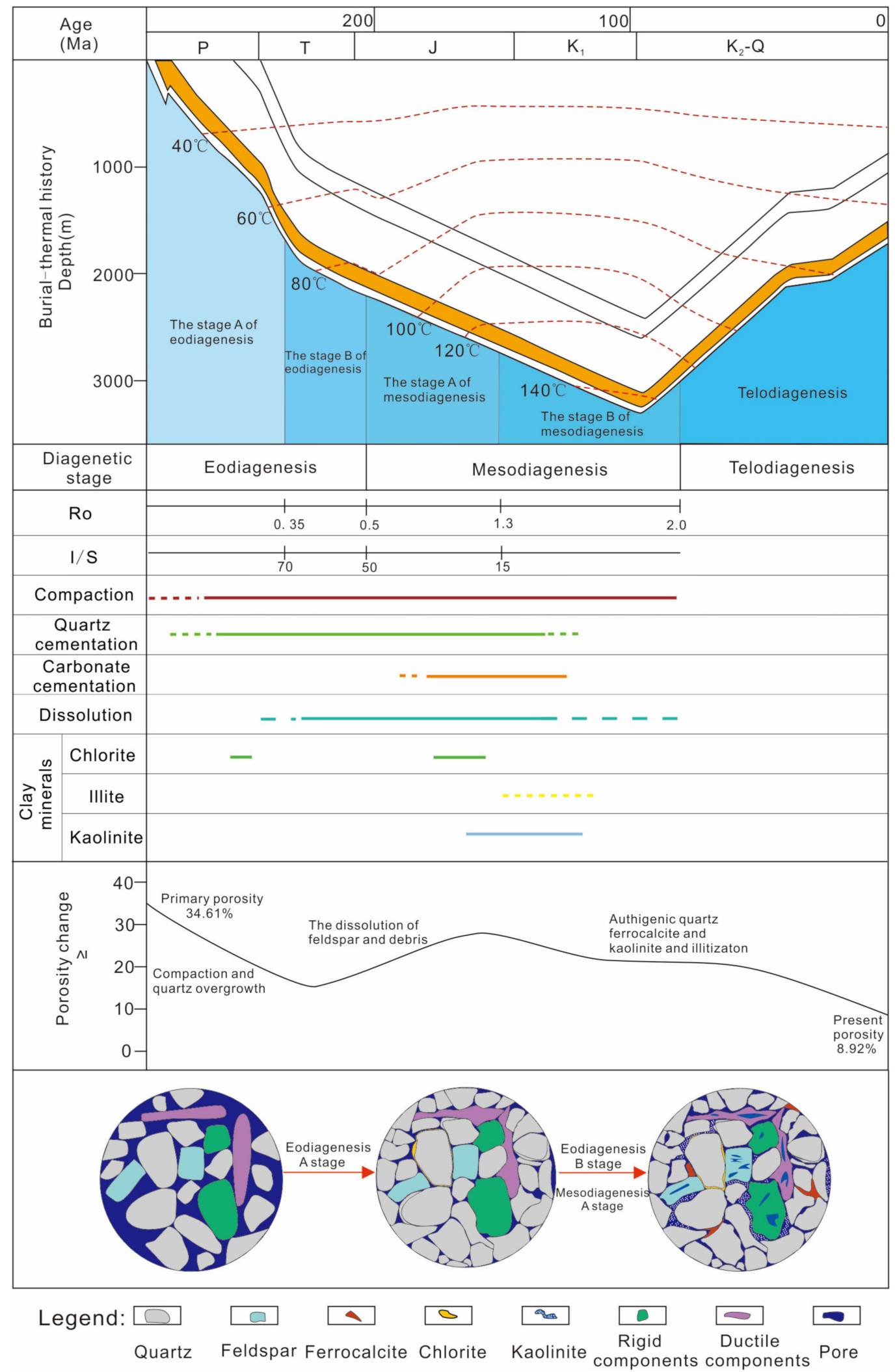

Figure 9. Diagenetic evolution sequence and pore evolution of sandstone of the Shanxi Formation in the HangJinqi area (Curve data of burial history from Xinhe Shao, 2018 [58]. Gas filling data from Zhou Jinsong, 2020 [59]). 


\subsubsection{Mesodiagenesis}

In the middle Jurassic-Early Cretaceous, the reservoir entered mesodiagenesis. In this period the burial depth was greater than $2200 \mathrm{~m}$, the temperature was higher than $85^{\circ} \mathrm{C}$, and $0.5 \%<\operatorname{Ro}<1.3 \%$ (Figure 9 ). At this stage, the temperature of fluid inclusions reached a secondary peak at $110-130^{\circ} \mathrm{C}$ (Figure 8) [49,51]. This is a mature hydrocarbon generation stage, and the basin slowly subsided. With the addition of organic acids, the chemical pressure solution continuously enhanced, forming plenty of dissolution pores and increasing the property and permeability of the sandstone reservoir. Carbonate, kaolinite, and illite blocked pores and reduced the physical properties. This phenomenon indicates that dissolution is the crucial reason for reservoir tightness. The reservoir of the Shanxi Formation in the Hanginqi area is currently in stage B of mesodiagenesis.

Therefore, compaction directly affected the reservoir tightness, and intense dissolution was beneficial to improve the physical properties of the reservoir.

Therefore, the diagenetic evolution sequence of the Shanxi Formation reservoir is as follows: compaction $\rightarrow$ quartz overgrowth, chlorite rim $\rightarrow$ iron-ferrocalcite calcite $\rightarrow$ feldspar dissolution $\rightarrow$ autogenous clay mineral cementation $\rightarrow$ authigenic quartz $\rightarrow$ ferrocalcite cementation $\rightarrow$ feldspar, rock fragments dissolved $\rightarrow$ kaolinite and illitization (Figure 9).

\section{Conclusions}

With the comprehensive analysis of petrological characteristics and reservoir properties at micro and macro scales, this study provides important insight into the diagenetic evolution, quantitative calculation of pore loss from diagenesis, and the determination of the time of different diagenetic of the Shanxi Formation in the Ordos Basin.

(1) The reservoir rock types of the Shanxi Formation are mainly sublitharenite and some litharenite. The porosity and permeability are positively correlated.

(2) During its lengthy geological history, the sandstones of the Shanxi Formation experienced eodiagenesis and mesodiagenesis, and general density. Carbonate, kaolinite, and illite cementation reduced the physical properties. Dissolution continuously enhanced during this time. The diagenetic evolution sequence is compaction $\rightarrow$ quartz overgrowth, chlorite rim $\rightarrow$ iron-ferrocalcite calcite $\rightarrow$ feldspar dissolution $\rightarrow$ autogenous clay mineral cementation $\rightarrow$ authigenic quartz $\rightarrow$ ferrocalcite cementation $\rightarrow$ feldspar, rock fragments dissolved $\rightarrow$ kaolinite and illitization.

(3) After these programs, a great number of intergranular dissolved pores, intragranular dissolved pores, moldic pores, and kaolinite intercrystalline pores appeared. Primary pores were greatly reduced, which was mainly affected by compaction. Porosity was also reduced by $32.75 \%$ and the average apparent compaction was $67.36 \%$. Cementation affected the quality of the reservoir to a certain extent, and the average cementation rate was $22.24 \%$. Dissolution has the ability to form secondary pores and improve reservoir physical properties. The average apparent dissolution rate was $80.76 \%$. The effect of dissolution on the reservoir was greater than that of compaction. Compaction directly affected the reservoir tightness, and intense dissolution was beneficial to improve the physical properties of the reservoir.

Author Contributions: Conceptualization, X.Z. (Xiang Zhang) and J.T.; methodology, J.T., J.L. and Q.L.; software, Y.Z. and X.Z. (Xiaoyu Zheng); validation, J.T.; formal analysis, Q.L. and J.L.; investigation, Y.Z., J.T. and X.Z. (Xiang Zhang); resources, J.T.; writing—original draft preparation, Y.Z.; writing—review and editing, J.T.; supervision, X.Z. (Xiang Zhang) and Q.L. All authors have read and agreed to the published version of the manuscript.

Funding: This research was funded by the Technology Major Project of the Ministry of Science and Technology of China (grant numbers 2016ZX05048).

Data Availability Statement: Not applicable.

Acknowledgments: Not applicable. 
Conflicts of Interest: The authors declare no conflict of interest.

\section{References}

1. Zou, C.N.; Zhang, G.Y.; Tao, S.Y.; Hu, S.Y.; Li, X.D.; Li, J.Z.; Dong, D.Z.; Zhu, R.K. Geological features, major discoveries and unconventional petroleum geology in the global petroleum exploration. Petrol. Explor. Dev. 2010, 37, 129-145. (In Chinese with English Abstract) [CrossRef]

2. Ghanizadeh, A.; Clarkson, C.R.; Awuino, S.; Ardakani, O.H.; Sanei, H. Petrophysical and geomechanical characteristics of Canadian tight oil and liquid-rich gas reservoirs: I. Pore network and permeability characterization. Fuel 2015, 153, 664-681. [CrossRef]

3. Jia, C.Z.; Zheng, M.; Zhang, Y.F. Unconventional hydrocarbon resources in China and the prospect of exploration and development. Petrol. Explor. Dev. 2012, 39, 139-146. (In Chinese with English Abstract) [CrossRef]

4. Liu, Q.Y.; Jin, Z.J.; Meng, Q.Q.; Wu, X.Q.; Jia, H.C. Genetic types of natural gas and filling patterns in Daniudi gas field, Ordos Basin, China. J. Asian Earth. Sci. 2015, 107, 1-11. [CrossRef]

5. Wu, X.Q.; Liu, Q.Y.; Zhu, J.H.; Li, K.; Liu, G.X.; Chen, Y.B.; Ni, C.H. Geochemical characteristics of tight gas and gas-source correlation in the Daniudi gas field, the Ordos Basin, China. Mar. Petrol. Geol. 2017, 79, 412-425. [CrossRef]

6. Dai, J.X.; Li, J.; Luo, X.; Zhang, W.Z.; Hu, G.Y.; Ma, C.H.; Guo, J.M.; Ge, S.G. Stable carbon isotope compositions and source rock geochemistry of the giant gas accumulations in the Ordos Basin, China. Org. Geochem. 2005, 36, 1617-1635. [CrossRef]

7. Yang, H.; Fu, J.H.; Liu, X.S.; Meng, P.L. Accumulation conditions and exploration and development of tight gas in the Upper Paleozoic of the Ordos Basin. Pet. Explor. Dev. Online 2012, 39, 315-324. (In Chinese with English Abstract) [CrossRef]

8. Zhang, S.C.; Mi, J.K.; Liu, L.H.; Tao, S.Z. Geological features and formation of coal-formed tight sandstone gas pools in China: Cases from Upper Paleozoic gas pools, Ordos Basin and Xujiahe Formation gas pools, Sichuan Basin. Pet. Explor. Dev. Online 2009, 36, 320-330. (In Chinese with English Abstract) [CrossRef]

9. Xiao, H.P.; Liu, R.E.; Zhang, F.D.; Lin, C.S.; Zhang, M.Y. Sedimentary model reconstruction and exploration significance of Permian He 8 Member in Ordos Basin, NW China. Petro. Explor. Dev. 2019, 46, 280-292. [CrossRef]

10. Cant, D.J.; Ethier, V.G. Lithology-dependent diagenetic control of reservoir properties of conglomerates, Father member, Elmworth field, Alberta. AAPG Bull. 1984, 68, 1044-1054.

11. Bjørlykke, K.; Jahren, J. Open or closed geochemical systems during diagenesis in sedimentary basins: Constraints on mass transfer during diagenesis and the prediction of porosity in sandstone and carbonate reservoirs. AAPG Bull. 2012, 96, 2193-2214. [CrossRef]

12. Bjørlykke, K. Relationships between depositional environments, burial history and rock properties. Some principal aspects of diagenetic process in sedimentary basins. Sedimen. Geol. 2014, 301, 1-14. [CrossRef]

13. Cant, D.J. Spirit River Formation; A stratigraphic-diagenetic gas trap in the deep basin of Alberta. AAPG Bull. 1983, 67, 577-587. [CrossRef]

14. Morad, S.; Ai-Ramadan, K.; Ketzer, J.M. The impact of diagenesis on the heterogeneity of sandstone reservoirs: A review of the role of depositional facies and sequence stratigraphy. AAPG Bull. 2010, 94, 1267-1309. [CrossRef]

15. Wang, G.W.; Chang, X.C.; Yin, W.; Li, Y.; Song, T.T. Impact of diagenesis on reservoir quality and heterogeneity of the Upper Triassic Chang 8 tight oil sandstones in the Zhenjing area, Ordos Basin, China. Mar. Petrol. Geol. 2017, 83, 84-96. [CrossRef]

16. Yuan, G.H.; Cao, Y.C.; Zhang, Y.C.; Gluyas, J. Diagenesis and reservoir quality of sandstones with ancient "deep" incursion of meteoric freshwater-An example in the Nanpu Sag, Bohai Bay Basin, East China. Mar. Petrol. Geol. 2017, 82, 444-464. [CrossRef]

17. Morad, S.; Ketzer, J.M.; De Ros, L.F. Spatial and temporal distribution of diagenetic alterations in siliciclastic rocks: Implications for mass transfer in sedimentary basins. Sedimentology 2000, 47, 95-120. [CrossRef]

18. Qiao, J.C.; Zeng, J.H.; Feng, X.; Yang, Z.F.; Zhang, Y.C.; Feng, S. Characteristics of Nano-Micro Pore Networks and Petroleum Microscopic Occurrence State in Ultra-Low Permeability (Tight) Sandstone Reservoir. J. Nanosci. Nanotechnol. 2017, 17, 6039-6050. [CrossRef]

19. Rossi, C.; Marfil, R.; Ramseyer, K.; Permanyer, A. Facies-related diagenesis and multiphase siderite cementation and dissolution in the reservoir sandstones of the Khatatba Formation, Egypt's Western Desert. J. Sedimen. Res. 2001, 71, 459-472. [CrossRef]

20. Lu, J.; Shao, L.Y.; Sun, B.B.; Yang, M.F.; Dong, D.X.; Tian, W.G.; Li, M.P. Sequence-paleogeography and coal accumulation of the Carboniferous-Permian in the North China Basin. Meitan Xuebao/J. China Coal Soc. 2014, 39, 1725-1734. [CrossRef]

21. Wang, C.Y.; Wang, Z.C.; Wang, J.L.; Bao, Y.; Hu, X.M. Reconstruction of paleo river systems and distribution of sedimentary facies of Shanxi and lower Shihezi formations in southern Ordos basin. J. China Univ. Min. Technol. 2008, 18, 241-244. [CrossRef]

22. Luo, J.L.; Li, J.; Li, B.H.; Dai, Y.Q.; Li, B.; Han, Y.L.; Wang, H.H.; Du, J.L. Provenance for the Chang 6 and Chang 8 Member of the Yanchang Formation in the Xifeng area and in the periphery Ordos Basin: Evidence from petrologic geochemistry. Sci. China Earth Sci. 2007, 50, 75-90. [CrossRef]

23. Li, Y.; Fan, A.P.; Yang, R.C.; Sun, Y.; Lenhardt, N. Sedimentary facies control on sandstone reservoir properties: A case study from the Permian Shanxi Formation in the southern Ordos basin, central China. Mar. Petrol. Geol. 2021, 129, 105083. [CrossRef]

24. Shan, X.; Yu, X.H.; Peter, C.; Zhou, J.S.; Du, Y.H.; Li, Y.L.; Su, D.X.; Jin, L.N. Sedimentology and Sequence Stratigraphy of Marine to Lacustrine Deltaic Deposits in a Craton Basin and Their Controlling Factors: Shan 2 Member-He 8 Member (GuadalupianLopingian, Permian), Southeast Ordos Basin, North China. Acta Geol. Sin. Engl. 2018, 92, 268-285. [CrossRef] 
25. Gao, X.D.; Wang, Y.B.; Li, Y.; Guo, H.; Ni, X.M.; Wu, X.; Zhao, S.H. Characteristics of Tight Sandstone Reservoirs and Controls of Reservoir Quality: A Case Study of He 8 Sandstones in the Linxing Area, Eastern Ordos Basin, China. Acta Geol. Sin. Engl. 2019, 93, 637-659. [CrossRef]

26. Qu, H.J.; Ma, Q.; Gao, S.L.; Mei, Z.C.; Miao, J.Y. Provence of the Permian in the Southeastern Ordos Basin. Acta Geol. Sin. 2011, 85, 979-986. (In Chinese with English Abstract)

27. Yang, R.C.; Fan, A.P.; Van Loon, A.J.; Han, Z.Z.; Wang, X.P. Depositional and Diagenetic Controls on Sandstone Reservoirs with Low Porosity and Low Permeability in the Eastern Sulige Gas Field, China. Acta Geol. Sin. Engl. 2014, 88, 1513-1534. [CrossRef]

28. Wang, W.R.; Yue, D.L.; Zhao, J.Y.; Li, W.; Wang, B.; Wu, S.H.; Li, S.H. Diagenetic alteration and its control on reservoir quality of tight sandstones in lacustrine deep-water gravity-flow deposits: A case study of the Yanchang Formation, southern Ordos Basin, China. Mar. Petrol. Geol. 2019, 110, 676-694. [CrossRef]

29. Wang, M.; Tang, H.M.; Tang, H.X.; Liu, S.; Cheng, Y.L. Impact of differential densification on the pore structure of tight gas sandstone: Evidence from the Permian Shihezi and Shanxi Formations, Eastern Sulige Gas Field, Ordos Basin, China. Geofluids 2019, 2019, 4754601. [CrossRef]

30. Xu, N.N.; Qiu, L.W.; Eriksson, K.A.; Klyukin, Y.I.; Wang, Y.; Yang, Y.Q. Influence of detrital composition on the diagenetic history of tight sandstones with implications for reservoir quality: Examples from the Permian Xiashihezi Formation and Carboniferous Taiyuan Formation, Daniudi gas field, Ordos Basin, China. Mar. Petrol. Geol. 2017, 88, 756-784. [CrossRef]

31. Zhou, T.Q.; Wu, C.D.; Shi, Z.K.; Wang, J.L.; Yang, D.S. Multi-Scale Quantitative Characterization of Pore Distribution Networks in Tight Sandstone by integrating FE-SEM, HPMI, and NMR with the Constrained Least Squares Algorithm. Energies 2019, $12,3514$. [CrossRef]

32. Du, W.; Jiang, Z.X.; Li, Q.; Zhang, Y. Sedimentary Characterization of the Upper Paleozoic Coal-Bearing Tight Sand Strata, Daniudi Gas Field, Ordos Basin, China. J. Earth Sci. China 2016, 27, 823-834. [CrossRef]

33. Yang, H.; Liu, X.H.; Yan, X.X.; Zhang, H. Discovery and reservoir-forming geological characteristics of the Shenmu Gas Field in the Ordos Basin. Nat. Gas Ind. B 2015, 2, 295-306. [CrossRef]

34. Yang, H.; Liu, X.H.; Yan, X.X.; Zhang, H. Diagenetic evolution of tight sandstone of Shanxi-Lower Shihezi Formation in the southern Ordos Basin. Nat. Gas Geosci. 2021, 32, 47-56. (In Chinese with English Abstract)

35. Liu, J.L.; Liu, K.Y.; Hunag, X. Effect of sedimentary heterogeneities on hydrocarbon accumulations in the Permian Shanxi Formation, Ordos Basin, China: Insight from an integrated stratigraphic forward and petroleum system modelling. Mar. Petrol. Geol. 2016, 76, 412-431. [CrossRef]

36. Bradley, D.R.; Andrew, D.H.; Brian, J.D.; Lynde, N.; Adrian, B. Sedimentary record of Triassic intraplate extension in North China: Evidence from the nonmarine NW Ordos Basin, Helan Shan and Zhuozi Shan. Tectonophysics 2004, 386, 177-202. [CrossRef]

37. Xiao, X.M.; Zhao, B.Q.; Thu, Z.L.; Song, Z.G.; Wilkins, R.W.T. Upper Paleozoic petroleum system, Ordos Basin, China. Mar. Petrol. Geol. 2005, 22, 945-963. [CrossRef]

38. Wu, X.Q.; Ni, C.H.; Liu, Q.Y.; Liu, G.X.; Zhu, J.H.; Chen, Y.B. Genetic types and source of the Upper Paleozoic tight gas in the Hangjinqi area, Northern Ordos Basin, China. Geofluids 2017, 2017, 2087-2093. [CrossRef]

39. Li, J.; Zhang, X.; Tian, J.C.; Liang, Q.S.; Cao, T.S. Effects of deposition and diagenesis on sandstone reservoir quality: A case study of Permian sandstones formed in a braided river sedimentary system, northern Ordos Basin, Northern China. J. Asian Earth Sci. 2021, 213, 104745. [CrossRef]

40. Yang, M.H.; Li, L.; Zhou, J.; Jia, H.C.; Sun, X.; Qu, X.Y.; Zhou, D.; Gong, T.; Ding, C. Mesozoic structural evolution of the Hangjinqi area in the northern Ordos Basin, North China. Mar. Petrol. Geol. 2015, 66, 695-710. [CrossRef]

41. Qu, H.J.; Ma, Q.; Gao, S.L.; Mei, Z.C.; Miao, J.Y. Controls of provenance and deposition facies on sandbody distribution of the Upper Paleozoic in Southern Ordos Basin. Acta Sedimentol. Sin. 2011, 29, 825-834. (In Chinese with English Abstract)

42. Li, S.X.; Xiang, F.; Zhang, Y.; Wang, Y.; Wang, J. Provence analysis of the late Paleozoic sediments in south margin of the Ordos Basin and its indication to evolution of the north of Qinling Orogenic Belt in China. J. Chengdu Univ. Technol. (Sci. Technol. Ed.) 2017, 44, 589-601. (In Chinese with English Abstract)

43. Zhu, Z.L.; Li, W.H.; Li, K.Y.; Chen, Q.H.; Guo, Y.Q.; Yuan, Z. The characteristic of sequence stratigraphy and sedimentary systems of Taiyuan-Xiashihezi formation in Hangjinqi area. J. Northwest Univ. (Nat. Sci. Ed.) 2010, 6, 1050-1053. (In Chinese with English Abstract)

44. Beard, D.C.; Weyl, P.K. Influence of texture on porosity and permeability of Unconsolidated sand. Am. Assoc. Pet. Geol. Bull. 1973, 57, 349-369. [CrossRef]

45. Liu, W.; Dou, Q.F. Study on diagenesis and diagenetic reservoir facies of the lower Member of J Jjf of Jiao 2 Block in KeErqin Oilfield. J. Xi'an Pet. Inst. (Sci. Technol. Ed.) 2003, 18, 4-8. (In Chinese with English Abstract)

46. Folk, R.L. Petrology of Sedimentary Rocks; Hemphill: Austin, TX, USA, 1980; p. 182.

47. Li, G.Z.; Qin, Y.; Shen, J. Geochemical characteristics of the Upper Paleozoic coal series shale in the Linxing area, Ordos Basin, China: Implications for paleoenvironment, provenance, and tectonic setting. Arab. J. Geosci. 2021, 14, 197. [CrossRef]

48. Ning, N.; Chen, M.J.; Liu, R.E.; Sun, Q.W.; Lin, J.; Xiao, H.P.; Zhang, C.L. Upper Paleozoic quartz-sandstone reservoir diagenesis and pore evolution, Eastern Ordos Basin. Nat. Gas Geol. 2007, 3, 334-338. (In Chinese with English Abstract) [CrossRef]

49. Zhao, G.Q.; Li, K.M.; Zhao, H.L.; Liu, R.E.; Li, Y.T. Feldspar corrosion and secondary pore formation in the Upper Paleozoic gas reservoir, Ordos Bain. Petrol. Expl. Dev. 2005, 32, 53-55+75. (In Chinese with English Abstract) [CrossRef] 
50. Li, B.; Peng, J.; Xia, Q.S.; Xie, J.T.; Han, M.J.Z. Diagenesis and reservoir quality of the Upper Triassic Chang 6 Member in Jingan Oilfield, Ordos Basin, China. Petroleum 2018, 4, 126-133. [CrossRef]

51. Lu, H.Z.; Fan, H.R.; Ni, P.; O, G.X.; Shen, K.; Zhang, W.H. Fluid Inclusion; Science Press: Beijing, China, 2004 ; pp. 154-170.

52. Zhao, G.P. Characterization of fluid inclusions and timing of gas accumulation in Upper Paleozoic reservoir of Hangjinqi area, Ordos Basin. Oil Gas Geol. 2017, 38, 905-912. (In Chinese with English Abstract) [CrossRef]

53. Lan, C.L.; Yang, M.H.; Zhang, Y.Z. Impact of sequence stratigraphy, depositional facies and diagenesis on reservoir quality: A case study on the Pennsylvanian Taiyuan sandstones, northeastern Ordos Basin, China. Mar. Petrol. Geol. 2016, 69, 216-230. [CrossRef]

54. Zhou, X.; He, S.; Chen, Z.Y.; Wang, F.R.; Zhou, S.B.; Liu, P. Diagenesis and diagenetic facies of low porosity and permeability sandstone in Member 8 of the Yanchang Formation in Daijiaping area, Ordos Basin. Oil Gas Geol. 2016, 37, 155-164. (In Chinese with English Abstract)

55. Gould, K.; Pe-piper, G.; Piper, D.J.W. Relationship of diagenetic chlorite rims to depositional facies in Lower Cretaceous reservoir sandstones of the Scotian Basin. Sedimentology 2010, 57, 587-610. [CrossRef]

56. Hakim, M.H.; Shalaby, M.R.; Abdullah, W.H. Diagenetic characteristics and reservoir quality of the Lower Cretaceous Biyadh sandstones at Kharir oilfield in the western central Masila Basin, Yemen. J. Asian Earth Sci. 2012, 51, 109-120. [CrossRef]

57. Huang, S.J.; Huang, K.K.; Feng, L.W.; Tong, H.P.; Liu, L.J.; Zhang, X.H. Mass exchange between feldspar, and illite and the formation of secondary pores during diagenesis: A study from the Upper Paleozoic in the Ordos Basin and the Triassic Formation in the western Sichuan depression. Geochemistry 2009, 38, 498-506. (In Chinese with English Abstract)

58. Shao, X.H.; Pang, X.Q.; Jiang, F.J.; Li, L.L.; Huyan, Y.Y.; Zheng, D.Y.; Ruffell, A. Diagenetic characteristics and reservoir quality in tight gas sandstones: A case study of the Shanxi Formation in the north-eastern Ordos Basin, China. Geol. J. 2018, 54, 3257-3271. [CrossRef]

59. Zhou, J.S.; Qiao, X.Y.; Wang, R.G.; Yin, X.; Liu, P. Characteristics and geological significance of fluid inclusions in the Lower Permian Shanxi Formation in the Yan'an Gas Field. Nat. Gas Ind. 2020, 40, 20-29. (In Chinese with English Abstract) [CrossRef] 